\title{
STUDI EKSPERIMEN TEPUNG MOCAF(MODIFIED CASSAVA FLOUR) MENJADI BROWNIES KUKUS
}

\author{
Putu Wahyu Manik Fransiska, Damiati, Ni Made Suriani \\ Jurusan Pendidikan Kesejahteraan Keluarga \\ Universitas Pendidikan Ganesha \\ Singaraja, Indonesia \\ e-mail: puja.wahyu17@gmail.com,damiati@undiksha.ac.id, \\ made.suriani@undiksha.ac.id
}

\begin{abstract}
Abstrak
Penelitian eksperimen ini bertujuan untuk mengetahui, (1) kualitas cake tepung mocaf dengan menggunakan bahan 100\% tepung mocaf dilihat dari aspek tekstur, rasa dan aroma, (2) proses pengolahan tepung mocaf menjadi brownies kukus. Metode pengumpulan data yang digunakan dalam penelitian ini yaitu metode observasi dengan menggunakan instrument berupa uji lembar organoleptik dengan 3 tingkat yaitu baik, cukup, dan kurang. Panelis dalam penelitian ini merupakan panelis terlatih yang terdiri dari26 orang panelis. Teknik analisis data yang digunakan teknik deskriptif kuantitatif. Hasil penelitian ini menunjukan kualitas brownies kukus tepung mocaf dengan menggunakan $100 \%$ tepung mocaf dilihat dari aspek (1) tekstur dengan skor rata-rata 2,85 berada pada kategori baik sesuai dengan tolak ukur lembut dan beremah, (2) aspek rasa dengan skor ratarata 2,95 berada pada kategori baik dengan tolak ukur memiliki rasa manis dan terasa coklat, (3) aspek aroma dengan skor rata-rata 2,85 berada pada kategori baik dengan tolak ukur dominan memiliki aroma coklat dan aroma khas tepung singkong.
\end{abstract}

Kata Kunci : Brownies Kukus, Kualitas, Tepung Mocaf.

\begin{abstract}
This experimental study aims to determine, (1) the quality of mocaf flour cake using $100 \%$ mocaf flour viewed from the aspect of texture, taste and aroma, (2) the processing of mocaf flour into steamed brownies. The data collection method used in this study is the observation method by using an instrument in the form of an organoleptic sheet test with 3 levels namely good, sufficient, and lacking. Panelists in this study were trained panelists consisting of 26 panelists. Data analysis techniques used are quantitative descriptive techniques. The results of this study show the quality of steamed mocaf flour using $100 \%$ mocaf flour seen from aspects (1) of the texture with an average score of 2.85 in the good category according to the soft and weak benchmark, (2) the taste aspect with the average score -ata 2.95 is in good category with a benchmark that has a sweet and brown taste, (3) the aroma aspect with an average score of 2.85 is in a good category with the dominant benchmark has a chocolate aroma and a distinctive aroma of cassava flour.
\end{abstract}

Keywords: Steamed Brownies, Quality,Mocaf Flour. 
Jurnal Bosaparis: Pendidikan Kesejahteraan Keluarga

Volume 10, Nomor 1, Maret 2019

\section{PENDAHULUAN}

Indonesia dikenal sebagai negara
agraris yang berarti negara yang
mengandalkan sektor pertanian sebagai
mata pencaharian maupun sebagai penopang pembangunan. Sektor pertanian merupakan penopang perekonomian di Indonesia karena pertanian membentuk proporsi yang sangat besar dan memberikan sumbangan untuk kas pemerintah. Hal ini kemudian menjadikan sektor pertanian sebagai pasar yang potensial bagi produk-produk dalam negeri baik untuk barang produksi maupun untuk barang konsumsi, terutama produk yang dihasilkan oleh sub sektor tanaman pangan.

Pangan dapat didefinisikan sebagai kebutuhan pokok manusia, sehingga semua orang pasti menginginkan kecukupan pangan. Kebutuhan akan pangan ini berkembang seiring dengan semakin meningkatnya jumlah penduduk suatu wilayah khususnya di Bali Utara.

Buleleng adalah kabupaten yang terluas di Pulau Bali dengan Singaraja sebagai pusat kota. Buleleng mempunyai 9 kecamatan dan 148 desa/kelurahan. Kecamatan Kubutambahan yang terletak di sebelah timur kota singaraja. Kubutambahan memiliki 6 desa antara lain; Bengkala, Bila, Bontihing, Bukti, Bulian, dan Depeha. diantara keenam desa tersebut, desa bukti merupakan desa penghasil singkong (kementrian pertanian). Singkong (manihot esculenta) merupakan bahan pengganti bagi beras dan jagung, singkong hanya diolah dengan cara dikukus, dijadikan tape singkong atau dijadikan gorengan lalu dinikmati sebagai camilan atau peneman minum kopi. Singkong mengandung sumber karbohidrat yang cukup potensial sebagai bahan penganekaragaman pangan. Selain sebagai sumber karbohidrat, singkong juga kaya akan air, protein dan antioksida. Pengolahan singkong menjadi bentuk setengah jadi misalnya tepung sehingga dapat disimpan lebih lama dan lebih praktis sehingga kesinambungan penyediaan bahan baku bagi industri menjadi lebih terjamin. Singkong temasuk tanaman perdu berbatang lunak atau getes (mudah patah) (Salim Emil,2011).

Singkong adalah bahan yang meiliki kandungan pati tinggi. Modifikasi bahan singkong dapat dilakukan secara kimiawi. Modifikasi pati secara kimiawi dapat dilakukan dengan menambahkan asam, oksida, coss-linking, starck esters, starck ethers, dan kationik. Midifikasi secara kimiawi dapat menyebabkan terjadinya cross-linking sehingga dapat memperkuat ikatan hydrogen dalam molekulpati (Yavuz,2003).

Ditinjau dari segi gizi, singkong kaya karbohidrat sebagai sumber kalori. Selain itu singkong juga mengandung sedikit lemak, hidrat arang, kalsium, fosfor, zat besi, serta vitamin B dan vitamin C. Singkon

$g$ merupakan sumber bahan makanan ketiga di Indonesia setelah padi dan jagung (salim emil, 2011).

Dengan banyaknya kreasi dalam dunia boga, kini singkong dapat diolah menjadi tepung yang disebut dengan modified cassava flour atau MOCAF. Tepung mocaf adalah tepung berbahan baku singkong atau ubi kayu yang dimodifikasi dengan teknik fermentasi menggunakan mikroba. Tepung mocaf memiliki karakteristik yang cukup baik untuk mensubstitusi atau menggantikan $100 \%$ penggunaan tepung terigu. Dibandingkan dengan tepung singkong tanpa fermentasi.

Tepung mocaf memiliki kualitas yang lebih bagus yaitu tampak lebih putih dibandingkan warna tepung singkong biasa. Selain itu, proses ini akan menghasilkan tepung yang secara karakteristik dan kualitas hampir menyerupai tepung terigu. Pada produk tepung singkong tanpa fermentasi warna kurang putih (coklat kehitaman) dan seringkali bau apek sangat kuat sehingga ketika diaplikasikan ke produk menyebabkan performan produk kurang menarik dan masih ada aroma khas singkong. Hal ini seringkali membuat industri olahan makanan yang berbahan 
Jurnal Bosaparis: Pendidikan Kesejahteraan Keluarga

Volume 10, Nomor 1, Maret 2019

baku tepung singkong atau gaplek menjadi kurang puas. Temuan tepung singkong modifikasi (mocaf) dimana karakteristik tepung mocaf lebih putih dan aroma singkong telah hilang sehingga jika mensubstitusi terigu tidak menurunkan kualitas produk jika proposi penggunaannya sesuai dengan jenis produknya.

Perinsip pembuatan tepung mocaf adalah memodifikasi sel singkong dengan cara fermentasi sehingga menyebabkan perubahan karakteristik yang dihasilkan berupa naiknya viskosita (daya rekat) sehingga tepung jenis ini mempunyai daya simpan yang cukup lama yaitu selama 6 bulan di suhu rugan dan 1 tahun di suhu kulkas.

Berdasarkan hasil yang sudah didapatkan kandungan gizi tepung mocaf, tepung singkong dan tepung terigu adalah sebagai berikut:

Tabel 1.1

Kandungan Gizi Tepung Terigu, Tepung Singkong, dan Tepung Mocaf dalam $100 \mathrm{gr}$

\begin{tabular}{cccc} 
Zat Gizi & $\begin{array}{c}\text { Tepung Terigu } \\
\text { perotein sedang }\end{array}$ & $\begin{array}{c}\text { Tepung } \\
\text { Singkong }\end{array}$ & $\begin{array}{c}\text { Tepung } \\
\text { Mocaf }\end{array}$ \\
Energi & $365 \mathrm{kal}$ & - & $358 \mathrm{kal}$ \\
Karbohidrat & $77.3 \mathrm{~g}$ & 34.00 & $88.6 \mathrm{~g}$ \\
Protein & $8.9 \mathrm{~g}$ & $1.2 \mathrm{~g}$ & $0.19 \mathrm{~g}$ \\
Air & 12.0 & 62.50 & 14.11 \\
Fosfor & $1.2 \mathrm{mg}$ & 40.00 & $7.0 \mathrm{mg}$ \\
Vitamin C & - & $30.00 \mathrm{mg}$ & - \\
Zat Besi & $1.2 \mathrm{mg}$ & $0.7 \mathrm{mg}$ & $1.58 \mathrm{mg}$ \\
Kalsium & $16.0 \mathrm{mg}$ & 33.00 & $20.0 \mathrm{mg}$ \\
Kalori (kkal) & 365 & 146.00 & - \\
Vitamin B1 & - & $0.06 \mathrm{mg}$ & - \\
Lemak & $1.3 \mathrm{~g}$ & $0.30 \mathrm{~g}$ & $0.02 \mathrm{~g}$ \\
Antioksidan & - & - & 17.26 \\
\hline Sumber : Direktorat Gizi Departemen Kesehatan R.I, 1996)
\end{tabular}

Berdasarkan table 1.1 di atas, tepung mocaf memiliki kandungan energi $358 \mathrm{kal}$, karbohidrat $88.6 \mathrm{~g}$, protein 0.19 , lemak $0,02 \mathrm{~g}$, zat besi $1.58 \mathrm{mg}$, kalsium $20.0 \mathrm{mg}$, fosfor $7.0 \mathrm{mg}$. Berdasarkan hal tersebut maka maka mocaf dapat digunakan sebagai substitusi tepung terigu. Akan tetapi, karena tepung mocaf tidak memiliki kandungan gluten. Oleh karena itu, penggunaan tepung mocaf untuk menyubstitusi tepung terigu hingga 100\% akan menurunkan kualitas produk olahan baik cita rasa maupun tampilan. Namun demikian, pada dasarnya tepung mocaf dapat menggantikan tepung terigu $100 \%$ pada produk-produk tertentu meskipun kualitasnya sedikit berbeda dibandingkan 
Jurnal Bosaparis: Pendidikan Kesejahteraan Keluarga

Volume 10, Nomor 1, Maret 2019

100\% menggunakan tepung terigu (Salim Emil,2011).

Brownies termasuk kue bantat yang sangat popular dikalangan masyarakat. Brownies biasanya dijual dalam bentuk kotak dan mika kecil. Brownies merupakan cake yang memiliki nilai jual yang cukup tinggi sehingga apabila tepung mocaf diolah menjadi brownies maka tepung mocaf yang belum memiliki nilai jual yang cukup tinggi akan memiliki nilai ekonomis yang tinggi. Brownies dapat dikatagorikan menjadi dua yaitu brownies panggang dan brownies kukus (Prakoso Pungky,2013). Dalam pembuatan brownies tepung mocaf penulis menggunakan $100 \%$ mocaf.

Pada tahap awal peneliti sudah melakukan pra eksperimen yang menggunakan subtitusi $50 \%$ dengan $50 \%$ yang menggunakan tepung mocaf dan tepung terigu, dari hasil produk yang dihasilkan menggunakan 50\% dengan 50\% tepung terigu dan tepung mocaf tekstur yang dihasilkan terlalu lembek. Peneliti melakukan eksperimen tahap ke dua yang menggunakan subtitusi $75 \%$ dengan perbandingan bahan $25 \%$ tepung terigu dan tepung mocaf. Perbandingan kandungan protein tepung mocaf $0.19 \mathrm{~g}$ sedangkan tepung terigu protein sedang mempunyai $8.9 \mathrm{~g}$ selain itu tekstur tepung mocaf sangat berbeda dengan tekstur tepung terigu. Tepung terigu memiliki tekstur dan sifat yang dapat mengikat sehingga kue yang dihasilkan akan menyatu dan membentuk kerangka dasar kue dengan baik, sedangkan tepung mocaf memiliki tekstur tepung yang tidak mengikat sehingga tepung mocaf tidak dapat membentuk kerangka dasar cakeapabila digunakan dengan formulasi $100 \%$ namun rasa yang dihasilkan kurang mencirikan brownies tepung mocaf. Sehingga peneliti menggunakan 100\% tepung mocaf dalam pembuatan brownies agar rasa tepung mocaf dari brownies tersebut menjadi ciri khas brownies tepung mocaf.
Dengan merunjuk pada pemaparan di atas maka penulis akan melakukan penelitian pembuatan brownies kukus dengan menggunakan bahan utama tepung mocaf menggunakan subtitusi 100\% yang bertujuan untuk memberikan tekstur, rasa, dan aroma. Tekstur pada brownies kukus lembut dan beremah, memiliki rasa manis dan dominan terasa coklat dan aroma dominan memiliki aroma khas coklat dan aroma khas tepung mocaf.

Hasil yang diharapkan dalam pembuatan brownies tepung mocaf ada tiga yaitu dari segi tekstur, rasa, aroma. brownies kukus tepung mocaf, tekstur brownies kukus yang diharapkan dalam penelitian ini adalah tekstur yang lembut dan berremah. Rasa yang diharapkan dari brownies tepung kulit mocaf adalah manis dan dominan terasa coklat. Aroma adalah hasil respon terhadap suatu produk yang dapat dinilai dengan bantuan indera penciuman. Aroma brownies kukus yang diharapkan dalam penelitian ini adalah dominan memiliki aroma khas coklat dan aroma khas tepung mocaf.

\section{METODE PENELITIAN}

Penelitian yang dilakukan adalah penelitian metode dengan pendekatan ekperimen laboratorium.

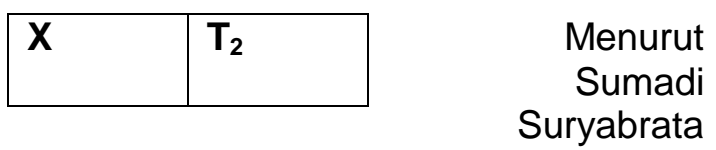

(1992:40), adapun rancangan eksperimen yang dipergunakan yaitu one-shot case study yang merupakan kelompok dikenakan perlakuan tertentu lalu setelah itu dilakukan pengukuran terhadap variabel tergantung. Variabel tergantung adalah variabel yang faktornya diamati dan diukur untuk menentukan pengaruh yang disebabkan oleh variabel bebas. Rancangan tersebut dapat digambarkan sebagai berikut : 
Jurnal Bosaparis: Pendidikan Kesejahteraan Keluarga

Volume 10, Nomor 1, Maret 2019

Keterangan :

$\mathrm{X} \quad$ : Perlakuan (pra eksperimen)

$\mathrm{T}_{2}$ : Observasi (pengambilan

data)

Langkah eksperimen yang akan digunakan dalam pembuatan brownies tepung mocaf mengacu pada resep dasar yang telah ditetapkan. Resep dasar brownies tepung mocaf telah mengalami proses substitusi anatar tepung mocaf dan tepung terigu..

Penelitian ini dilakukan di laboratorium produksi boga jurusan Pendidikan Kesejahteraan Keluarga, Fakultas Teknik dan Kejuruan, Universitas Pendidikan Ganesha dan dirumah, sedangkan untuk waktu pelaksanaan penelitian pada tahun 2018.

Variable penelitian merupakan suatu objek penelitian atau gejala yang menjadi fokus segala objek yang menjadi titik perhatian suatu penelitian (Arikunto, 2002:96). Variable dalam penelitian ini adalah pengolahan tepung mocaf menjadi brownies kukus dari aspek tekstur, rasa dan aroma

diuji $\begin{gathered}\text { Dalam studi eksperimen brownies } \\ \text { kualitasnya mempergunakan uji }\end{gathered}$ organoleptik yang meliputi penilaiaan terhadap tekstur, rasa, dan aroma. Uji organoleptik merupakan penilaiaan dengan mempergunakan indera manusia. Penilaian organoleptik digunakan untuk menilai mutu komoditi makanan. Uji organoleptik yang digunakan dalam penelitian ini adalah uji mutu hedonik yaitu penilaian yang dilakukan oleh panelis tentang baik buruknnya suatu produk makanan. Dalam uji mutu hedonik ini, panelis diminta tanggapan peribadinya tentang kualitas suatu produk makanan (Soekarto, 1985). Uji mutu hedonik bertujuan untuk mengetahui tanggapan panelis terhadap kualitas brownies tepung mocaf, dilihat dari segi tekstur, rasa, dan aroma.

Panelis dalam penelitian ini yaitu panelis terlatih. Panelis terlatih ini merupakan seseorang yang sudah ahli atau sudah bisa menilai baik buruknya kualitas brownies nantinya. Panelis ini berjumlah 1525 orang yang biasanya diambil dari personal laboratorium tetapi dapat pula karyawan atau pegawai lain (Soekarto, 1985). Dalam penelitian ini digunakan 26 orang panelis terlatih yang berasal dari Dosen Pendidikan Kesejahteraan Keluarga Prodi Tata Boga, Guru-Guru SMK/ Tata Boga, dan pihak Hotel Aneka/ Restaurant.

Panelis menganggapi dengan cara memberikan tanda check list $(\sqrt{ })$ sesuai dengan kriteria yang telah ditentukan pada lembar observasi panelis terhadap kualitas brownies tepung mocaf yang berdasarkan tes skala mutu hedonik. Pada mutu hedonik, data penilaian dapat ditransformasikan dalam sekala numerik dan selanjutnya dapat dianalisis statistik untuk interpretasinya (Soekarto, 1985). skala mutu hedonik yang digunakan yaitu rentangan tiga tingkatan. Nilai yang diberikan pada setiap panelis adalah 1 . Kurang 2. Cukup 3. Baik, serta dapat diaplikasikan dalam skala numerik pada table.

Tujuan yang diharapkan dari penelitian ini adalah untuk mengetahui kualitas brownies kukus tepung mocaf ditinjau dari tekstur, rasa dan aroma. Maka sesuai dengan tujuan penelitian ini menggunakan metode analisi deskriptif kuantitatif yaitu suatu cara pengolahan data yang dilakukan dengan jalan menyusun angka secara sistematis dalam bentuk presentase mengenai suatu objek yang akan diteliti, sehingga diperoleh kesimpulan umum ( Agung 1999 : 76).

Data uji kualitas tekstur, rasa, dan aroma dipersentasikan dengan mengunakan rumus

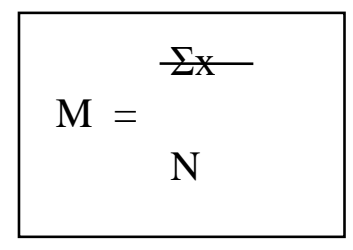


Jurnal Bosaparis: Pendidikan Kesejahteraan Keluarga

Volume 10, Nomor 1, Maret 2019

Keterangan Rumus :

$$
\begin{aligned}
& \mathrm{M}= \text { Mean (rata-rata) } \\
& \Sigma \mathrm{X}= \text { Jumlah masing-masing } \\
& \text { skor terhadap kualitas } \\
& \text { brownies kukus tepung } \\
& \text { mocaf } \\
& \mathrm{N}= \text { Jumlah subjek (sampel) } \\
& \text { (Arikunto, 2002) }
\end{aligned}
$$

Rumus pedoman konversi dengan skala 3 (tiga)

$$
\begin{aligned}
& \mathrm{M}+1 \mathrm{SD} \longrightarrow \mathrm{M}+3 \mathrm{SD} \quad \text { (Baik) } \\
& \mathrm{M}-1 \mathrm{SD} \longrightarrow \mathrm{M}+1 \mathrm{SD} \\
& \text { (Cukup) } \\
& \mathrm{M}-3 \mathrm{SD} \longrightarrow \mathrm{M}-1 \mathrm{SD} \\
& \text { (Buruk) } \\
& \mathrm{M} \quad=\text { Mean } \\
& \text { SD = Standar Deviasi (Koyan, } \\
& \text { 2011:122) }
\end{aligned}
$$

$\mathrm{SD}=$ Standar Deviasi yang dicari dengan rumus :

$\mathrm{SD}=\frac{1}{6} \times($ Skor Maksimum - Skor Minimum)

Skor maksimum $=3$

Skor minimum $\quad=1$

Berdasarkan rumus diatas, maka data yang sudah terkumpul akan dicari konversinya. Sehingga mendapatkan hasil sebagai berikut:

$M=\frac{1}{2} \times($ Skor Maksimum + Skor Minimum $)$

$M=\frac{1}{2} \times(3+1)$

$\mathrm{M}=2$

$\mathrm{SD}=\frac{1}{6} \times($ Skor Maksimum - Skor

Minimum)

$\mathrm{SD}=\frac{1}{6} \times(3-1)$

$\mathrm{SD}=0,33$
Acuan pengambilan keputusan yang digunakan untuk menentukan kualitas brownies tepung biji keluwih dari segi rasa dan tekstur berdasarkan rumus pedoman konversi dengan skala tiga adalah sebagai berikut:

$$
\begin{array}{ll}
2,33-3 & =\text { Baik } \\
1,67-2,32 & =\text { Cukup } \\
1-1,66 & =\text { Buruk }
\end{array}
$$

\section{HASIL PENELITIAN DAN PEMBAHASAN}

\section{Hasil Penelitian}

\section{Proses Pengolahan Brownies Kukus Tepung Mocaf}

Kualitas Brownies kukus dengan subtitusi tepung mocaf dilihat dari aspek tekstur, rasa , dan aroma. Proses pengolahan Brownies kukus tepung mocaf dengan menggunakan resep baku Brownies kukus tepung terigu. Brownies kukus tepung mocaf dibuat dengan $100 \%$ menggunakan tepung mocaf hasil yang dihasilkan sudah sesuai dengan kriteria Brownies kukus pada umumnya. Adapun proses penggolahan Brownies kukus sebagai berikut: 1. Tahap persiapan bahan, 2. Tahap persiapan alat, dan 3. Tahap pengolahan.

\section{Kualitas Tepung Mocaf Menjadi Brownies Kukus Yang Dilihat Dari Aspek Tekstur, Rasa, Dan Aroma.}

Berdasarkan kualitas brownies kukus tepung mocaf yang dibuat oleh peneliti dilaboratorium, memperoleh suatu hasil cake yang menggunakan 100\% tepung mocaf, yang dibuat sesuai dengan resep kontrol, dapat memenuhi kriteria hasil yang dilihat dari tiga (3) aspek yaitu : tekstur, rasa, dan aroma. Tekstur adalah keadaan suatu permukaan. Tekstur brownies yang diharapkan dalam penelitian ini adalah tekstur yang Lembut dan berremah. Rasa adalah tanggapan indera terhadap rangsangan saraf seperti manis, 
Jurnal Bosaparis: Pendidikan Kesejahteraan Keluarga

Volume 10, Nomor 1, Maret 2019

pahit, asam, terhadap indera pengecap. Rasa yang diharapkan dari brownies tepung mocaf adalah manis dan dominan terasa coklat. Aroma adalah hasil respon terhadap suatu produk yang dapat dinilai dengan bantuan indera penciuman. Aroma brownies yang diharapkan dalam penelitian ini adalah dominan memiliki aroma khas coklat dan aroma khas tepung mocaf.

Tekstur yang diperoleh dari hasil laboratorium yang diuji kualitas brownies kukus tepung mocaf yang dilihat dari aspek tekstur memiliki lembut dan berremah yang sudah sesusai dengan tiori brownies kukus.

Rasa yang dihasilkan dari uji kualitas brownies kukus tepung mocaf memiliki rasa manis, yang dihasilkan dari gula, dan coklat. Rasa brownies kukus tepung mocaf memiliki rasa manis dan dominan terasa coklat sesuai dengan kontrol dan kajian tiori.

Dalam menentukan aroma dalam suatu produk makanan, ditentukan dengan bantuan indra penciuman. Tekstur yang dihasilkan dari brownies kukus tepung mocaf memiliki aroma dominan memiliki aroma khas coklat dan aroma khas tepung mocaf yang sudah sesuai dengan tiori-tiori cake pada umumnya.

\section{Pembahasan}

\section{Proses Pengolahan Brownies Kukus Tepung Mocaf}

Kualitas Brownies kukus dengan subtitusi tepung mocaf dilihat dari aspek tekstur, rasa , dan aroma. Proses pengolahan Brownies kukus tepung mocaf dengan menggunakan resep baku Brownies kukus tepung terigu. Brownies kukus tepung mocaf dibuat dengan $100 \%$ menggunakan tepung mocaf hasil yang dihasilkan sudah sesuai dengan kriteria Brownies kukus pada umumnya. Adapun tahapan-tahapan dalam proses pembuatan Brownies Kukus, yang pertama menyiapkan bahan-bahan yang akan digunakan antara lain Tepung Mocaf, Baking Powder, Coklat Bubuk, Susu Bubuk, Vanili Bubuk, Telur, Garam, Gula Pasir, Minyak Goreng, Mentega, Dark cooking chocolate. Kemudian untuk alat yang digunakan antara lain Timbangan, Mixer Kompor, Bowl Loyang, Pengukusan, Ayakan, Gelas ukur, Panci coklat tim, Spatula, Pisau, Sendok the, Sendok makan, Kuas, Bowl besar, Plate, Serbet, Pisau roti, Mika, Kertas roti.

Setelah bahan dan alat sudah siap baru dilanjutkan ke tahap pengolahan dimana tahap pertama Panaskan kukusan dengan api sedang. Oles loyang dengan margarine dan alasi dengan baking paper. Lalu campurkan mentega dan dark cooking chocolate, lalu lelehkan selama 5 menit, kocok telur dan gula pasir hingga mengembang dan kental Selama 15 menit. Setelah itu masukan campuran tepung mocaf, baking powder, coklat bubuk, vanili bubuk, susu bubuk, dan garam yang sudah diayak sebelumnya. Tuangkan campuran mentega dan dark cooking chocolate, lalu aduk balik dengan mengunakan spatula hingga rata dan tidak ada endapan cairan dibawahnya. Tuangkan adonan kedalam loyang kukus selama 45 menit. Kemudian keluarkan loyang dari kukusan. Tunggu hingga dingin, baru keluarkan brownies dari loyang. Potong dan sajikan.

\section{Kualitas Brownies Kukus Tepung Mocaf Dari Aspek Tekstur}

Tekstur adalah jalinan atau penyatuan bagian-bagian sesuatu sehingga membentuk suatu benda. Dalam menentukan tekstur suatu produk makanan, dapat ditentukan dengan cara dipotong, diiris, maupun ditekan dengan ujung jari tangan atau meraba pada permukaan makanan. Tekstur dari suatu hidangan dapat mempengaruhi penampilan hidangan yang disajikan. 
Jurnal Bosaparis: Pendidikan Kesejahteraan Keluarga

Volume 10, Nomor 1, Maret 2019

Dari hasil uji panelis yang dilakukan, diketahui bahwa brownies kukus tepung mocaf dilihat dari aspek tekstur memperoleh skor rata-rata 2,85 dan sebanyak 22 orang panelis menyatakan tekstur dari brownies kukus tepung mocaf memiliki tekstur lembut dan berremah. Dan 4 orang panelis menyatakan tekstur brownies kukus tepung mocaf terlalu lembuat dan tidak berremah. Sehingga kualitas brownies kukus tepung mocaf berada pada kategori baik sesuai dengan tolok ukur yang telah ditentukan yaitu lembut dan beremah, brownies kukus tepung mocaf memiliki tekstur lembut sesuai dengan resep baku yang sudah dipergunakan. Berdasarkan dari hasil penelitian yang didapat hasil dari brownies kukus tepung mocaf sudah sesuai dengan teori yang terdapat pada kajian pustaka yang menyatakan tekstur dari brownies kukus yang baik adalah bertekstur lembut dan beremah, yang mempenggaruhi lembut dan berremahnya adalah mentega dan telur.

\section{Kualitas Brownies Kukus Tepung Mocaf Dari Aspek Rasa}

Rasa adalah hasil respon terhadap suatu makanan dari penilaian indra pencicip. Rasa dapat dipengaruhi oleh bahan yang digunakan. Kriteria rasa kue kering yang baik dapat dipengaruhi oleh bahan yang digunakan. Cara yang dapat dilakukan untuk menentukan rasa dari kue kering adalah dengan mencicipi kue kering tersebut secara langsung.

Hasil uji kualitas brownies kukus tepung mocaf dari aspek rasa yang diperoleh dari 24 orang panelis terlatih memperoleh skor rata-rata 2,92. Sebanyak 2 orang panelis menyatakan dari aspek rasa brownies kukus tepung mocaf memiliki rasa manis dan tidak terasa coklat. Dari 24 komentar yang diberikan oleh panelis brownies kukus tepung mocaf ini sudah sesuai dengan resep baku yang digunakan, hal ini menyebabkan kualitas rasa brownies kukus tepung mocaf berada pada kategori baik sesuai dengan tolak ukur yang ditentukan.

Brownies kukus yang dibuat sesuai resep baku menghasilkan rasa manis. Dalam penelitian ini rasa yang di peroleh sesuai dengan teori yang terdapat pada kajian pustaka yang menyatakan brownies kukus tepung mocaf memiliki rasa manis. Rasa melibatkan lidah sebagai indra perasa (Soekarto,1985:58). Cara yang baik untuk menentukan rasa dari brownies kukus adalah dengan mencicipi kue tersebut secara langsung. Rasa yang diharapkan pada pembuatan brownies kukus tepung mocaf adalah rasa manis.

\section{Kualitas Brownies Kukus Tepung Mocaf Dari Aspek Aroma}

Aroma merupakan hasil respon terhadap suatu produk yang dapat dinilai dengan bantuan indera penciuman. Hasil uji kualitas brownies kukus tepung mocaf dari aspek aroma yang diperoleh dari 26 orang panelis terlatih memperoleh skor rata-rata 2,85. Sebanyak 4 orang panelis menyatakan dari aspek aroma brownies kukus tepung mocaf memiliki aroma khas coklat dan tidak beraroma khas tepung singkong. Dari beberapa komentar yang diberikan oleh panelis brownies kukus tepung mocaf ini sudah sesuai dengan resep baku yang digunakan, hal ini menyebabkan kualitas rasa brownies kukus tepung mocaf berada pada kategori baik sesuai dengan tolak ukur yang ditentukan.

brownies kukus yang dibuat sesuai resep baku menghasilkan aroma coklat. Dalam penelitian ini aroma yang di peroleh sesuai dengan teori yang terdapat pada kajian pustaka yang menyatakan brownies kukus tepung mocaf memiliki aroma coklat. Cara yang baik untuk menentukan aroma dari brownies kukus adalah dengan indra penciuman tersebut secara langsung. Aroma yang diharapkan pada pembuatan brownies kukus tepung mocaf adalah 
Jurnal Bosaparis: Pendidikan Kesejahteraan Keluarga

Volume 10, Nomor 1, Maret 2019

dominan memiliki aroma khas coklat dan aroma khas tepung singkong.

\section{PENUTUP \\ Simpulan}

Berdasarkan hasil penelitian yang dilakukan, maka dapat disimpulkan sebagai berikut.

\section{Proses Pengolahan Brownies Kukus Tepung Mocaf}

Kualitas Brownies kukus dengan subtitusi tepung mocaf dilihat dari aspek tekstur, rasa, dan aroma. Proses pengolahan Brownies kukus tepung mocaf dengan menggunakan resep baku Brownies kukus tepung terigu. Brownies kukus tepung mocaf dibuat dengan $100 \%$ menggunakan tepung mocaf hasil yang dihasilkan sudah sesuai dengan kriteria Brownies kukus pada umumnya. Adapun tahapan-tahapan dalam proses pembuatan Brownies Kukus, yang pertama menyiapkan bahan-bahan yang akan digunakan antara lain Tepung Mocaf, Baking Powder, Coklat Bubuk, Susu Bubuk, Vanili Bubuk, Telur, Garam, Gula Pasir, Minyak Goreng, Mentega, Dark cooking chocolate. Kemudian untuk alat yang digunakan antara lain Timbangan, Mixer Kompor, Bowl Loyang, Pengukusan, Ayakan, Gelas ukur, Panci coklat tim, Spatula, Pisau, Sendok the, Sendok makan, Kuas, Bowl besar, Plate, Serbet, Pisau roti, Mika, Kertas roti.

Setelah bahan dan alat sudah siap

baru dilanjutkan ke tahap pengolahan dimana tahap pertama Panaskan kukusan dengan api sedang. Oles loyang dengan margarine dan alasi dengan baking paper. Lalu campurkan mentega dan dark cooking chocolate, lalu lelehkan selama 5 menit, kocok telur dan gula pasir hingga mengembang dan kental Selama 15 menit. Setelah itu masukan campuran tepung mocaf, baking powder, coklat bubuk, vanili bubuk, susu bubuk, dan garam yang sudah diayak sebelumnya. Tuangkan campuran mentega dan dark cooking chocolate, lalu aduk balik dengan mengunakan spatula hingga rata dan tidak ada endapan cairan dibawahnya. Tuangkan adonan kedalam loyang kukus selama 45 menit. Kemudian keluarkan loyang dari kukusan. Tunggu hingga dingin, baru keluarkan brownies dari loyang. Potong dan sajikan.

\section{Kualitas Tepung Mocaf Menjadi Brownies Kukus Yang Dilihat Dari Aspek Tekstur, Rasa, Dan Aroma.}

Hasil uji kualitas kue brownies kukus dari aspek tekstur yang kategori baik yaitu lembut dan beremah yang memperoleh skor rata-rata 2,85, sedangkan dari aspek rasa memperoleh skor 2,95 berada dalam kategori baik yaitu memiliki rasa manis dan terasa coklat, sedangkan dari aspek aroma memperoleh skor rata-rata 2,85 , memiliki kategori baik yaitu memiliki aroma coklat dan aroma khas tepung singkong.

\section{Saran}

Berdasarkan simpulan penelitian yang telah dikemukakan, maka diajukan beberapa saran. Saran-saran yang dimaksud yaitu sebagai berikut :

1. Dalam pembuatan brownies kukus sebaiknya menggunakan $100 \%$ tepung mocaf dengan takaran yang ditentukan agar tercipta rasa, aroma dan tekstur yang mencirikan tepung mocaf itu sendiri.

2. Kepada peneliti selanjutnya dalam pembuatan brownies kukus tepung mocaf sebaiknya tidak menggunakan subtitusi tepung terigu tepung mocaf $50 \% \quad 50 \%$ karena hasil produknya terlalu lembek. 
Jurnal Bosaparis: Pendidikan Kesejahteraan Keluarga

Volume 10, Nomor 1, Maret 2019

\section{DAFTAR RUJUKAN}

Agung, A.A. Gede. 1999.Metodelogi Penelitian Pendidikan. Singaraja: STKIP Singaraja.

Anonim. 2015. "Wikipedia Kabupaten Buleleng" tersedia pada https://baliterkini.wordpress.com/20 09/09/05/kabupaten-buleleng/ (diakses tanggal 21 juli 2017)

Anonim. 2015. "Pengertian Brownies" https://dhesiana.wordpress.com/20 16/06/09/apakah-tepung-mocaf-itu/ (diakses pada 21 juli 2017)

Anonim. 2015. "Pengertian Singkong Dan Jenis-Jenis Singkong" tersedia pada

http://www.untukku.com/artikeluntukku/pengertian-singkonguntukku.html (diakses tanggal 21 juli 2017)

Anonim. 2015. "Ketela Pohon, Sejarah Dan Pengaruh Ekonomi" tersedia pada

https://id.wikipedia.org/wiki/Ketela pohon\#Sejarah dan pengaruh ekonomi (diakses tanggal 21 juli 2017)

Anonim. 2015. "Pengolahan Tepung Mocaf Jurnal Kampus" Tersedia pada https://scholar.google.co.id/scholar ?start $=110 \& q=$ pengolahan+tepung +mocaf+jurnal+kampus\&hl=id\&as $\mathrm{sdt}=0,5 \& a s$ vis $=1$ (diakses tanggal 20 juli 2017)

Amilia, Winda. (2014)."Pengembangan Produk Baru Berbahan Dasar MOCAF (Modified Cassava Flour) sebagai Produk Oleh-Oleh Khas Kabupaten Jember Dalam Pembuatan Pie Tape, dan Pie Edamame", Jurusan Teknik
Pertanian, Fakultas Teknologi Pertanian, Universitas Jember.

Asyaukani, M.T. 2008. Modified Cassava Flour as Indigenous Processed Food toStrengthen Food Security in Indonesia. International Forum Student - TUA.IPB.

Budiningsih, A. \& Syamsul, M. 2017. Produk cake dan kue Indonesia. Bogor: Yudistira

Budiningsih, A. \& Syamsul, M. 2017. Pengolahan dan penyajian makanan. Bogor: Yudistira

Budiningsih, A. \& Syamsul, M. 2016. Pengetahuan bahan makanan. Bogor: Yudistira

Budiningsih, A., Wahdatulaili, K., Kusumaningtyas, W. 2015. IImu Gizi. Bogor: Yudistira

Iva Rosmeri, Vinsensia dan Nina Monica, Bella (2013)."Pemanfaatan Tepung Umbi Gadung (Dioscorea hispida Dennst) dan Tepung MOCAF (Modified Cassava Flour) sebagai Bahan Substitusi dalam Pembuatan Mie Basah, Mie Kering, Mie Instan", Fakultas Teknik, Universitas Diponegoro (hlm.246256).

Ira Wahdini, Annisaa, Susilo, Bambang, dan Yulianingsih, Rini (2014)."Uji Karakteristik Mi Instan Berbahan Dasar Tepung Terigu dengan Subtitusi Mocaf dan Pati Jagung", Jurusan Keteknikan Pertanian, Fakultas Teknologi Pertanian, Universitas Brawijaya (hal.234245).

Marsiti, Cok Istri Raka. 2005. Patiseri 2. Singaraja: PKK/Pendidikan Teknologi Dan Kejuruan. 
Jurnal Bosaparis: Pendidikan Kesejahteraan Keluarga

Volume 10, Nomor 1, Maret 2019

Nanda Arimbi, Agnessia dan Bahar, Asrul (2013)."Pengaruh Bubtitusi Tepung Mocaf (Modified Cassava Flour) dan Penambahan Puree Wortel (Daucus carota L) Terhadap Mutu Organoleptik Roti Tawar", Jurusan Pendidikan Kesejahteraan Keluarga, Fakultas Teknik, Universitas Negeri Surabaya (hal.114-121).

Prakoso, P. 2013. Pastry \& bakery brownie. Jakarta: Demedia

P. Sari lke, 2013, ragam kudapan singkong, katahati, Yogyakarta, perpustakaan nasional : catalog dalam terbitan (hal 80)

R, Hanifa, Hintono, A, dan Pramono, Y.B (2013)."Kadar Protein, Kadar Kalsium, dan Kesukaan Terhadap Cita Rasa Chiken Nugget Substitusi Terigu dengan Mocaf dan Penambahan Tepung Tulang Rawan", Fakultas Pertanian dan Peternakan, Universitas Diponegoro Semarang.

Salim, E. 2011. Mengolah singkong menjadi tepung mocaf. Yogyakarta: Lily publisher
Sawega, A.M., 2007. Kembali ke Kassava. Kuliner Indonesia KeanekaragamanPangan. www.Kuliner Indonesia (kliping kuliner \& wisata Nusantara) Keanekaragaman Pangan.htm.

Suparta I Made, 2007, Tepung Mocaf, Kelompok Tani Kerti Winangun alamat dusun sanih, desa bukti, kecamatan kubutambahan, kab buleleng.

Sugiyono, 2015. Metode Penelitian Kuantitatif. Kualitatif, dan R\&D. Badung: Alfabeta

Sukardi. 2010. Metode Penelitian Pendidikan Kompetensi Dan Prakteknya. Jakarta: Bumi Aksara

Soekarto, Soewarno T, 1985. Peneliatian Organoleptik. Jakarta: Bhatara Karya Aksara

Tim Penyusun Kamus Pusat Bahasa. 2005. Kamus Besar Bahasa Indonesia edisi ke tiga, Jakarta: Balai Pustaka

Tim Penyusun Kamus Pusat Bahasa. 2012. Kamus Besar Bahasa Indonesia edisi ke empat, Jakarta: Balai Pustaka 